\title{
Corporate bee accountability among Swedish companies
}

Book or Report Section

Accepted Version

Kristina, J. and Rimmel, G. (2016) Corporate bee accountability among Swedish companies. In: Atkins, J. and Atkins, B. (eds.) The Business of Bees. Greenleaf Publishing, pp. 260-276. ISBN 9781783535224 Available at http://centaur.reading.ac.uk/73615/

It is advisable to refer to the publisher's version if you intend to cite from the work. See Guidance on citing.

Publisher: Greenleaf Publishing

All outputs in CentAUR are protected by Intellectual Property Rights law, including copyright law. Copyright and IPR is retained by the creators or other copyright holders. Terms and conditions for use of this material are defined in the End User Agreement. 


\section{CentAUR}

Central Archive at the University of Reading

Reading's research outputs online 


\title{
14 \\ Corporate bee accountability among Swedish companies
}

\section{Kristina Jonäll}

\author{
Gothenburg University, Sweden
}

\section{Gunnar Rimmel \\ Jönköping University, Sweden}

Imagine billions of workers who work without a break, in silence and without pay. This is the reality for bees. For a long time no one saw any value in the work they do. It has taken a tragedy for us to understand their economic value. In the US a large part of the natural wild bee population has died off; the same thing has happened in Europe. ${ }^{1}$

Pollinating insects are vital for the ecosystem to function, for the global economy, for modern consumer culture and for human survival. Without bees and other pollinators, more than $50 \%$ of the food we consume would disappear or sharply rise in price. ${ }^{2}$ Primary vegetables, fruit and berries are pollinated by bees. Meat and dairy products are dependent on pollinators, since large proportions of livestock fodder such as clover or alfalfa require pollination. Cotton is also pollinated by insects, as well as rubber trees. So without bees humans would have to live without jeans, T-shirts or sneakers, as well as refreshing fruits or a cup of coffee in the morning. Most of us would survive solely on corn, rice and windpollinated grains, but we would probably suffer from deficiency diseases such as scurvy.

In landscapes where wild pollinators are decreasing, honey bees promote the maintenance of plant species; therefore honey bee losses are of great concern. Current honey bee colony losses worldwide are caused by colony collapse disorder, the mite Varroa destructor and pesticides. ${ }^{3}$ One of the first alarms raised concerning mass bee death came from a beekeeper in Florida in November 2006 who discovered that his bees had

\footnotetext{
${ }^{1}$ D. van Engelsdorp et al., "Colony Collapse Disorder: A Descriptive Study”, PLoS ONE (2009).

2 J. Sass, Busy as a Bee: Pollinators Put Food on the Table (National Resources Defense Council, 2015); N. Holland, “The Economic Value of Honeybees”, BBC News, 2009.

${ }^{3}$ T.R. Pedersen et al., Massdöd av bin - samhällsekonomiska konsekvenser och möjliga åtgärder (Rapport 2009:24) (Jönköping: Jordbruksverket, 2009).
} 
disappeared. ${ }^{4}$ Further reports showed that the phenomenon could be found in the USA, Canada and it was also detected in Germany, France, Holland and Italy.

Although much is still to be researched and explained about massive bee death, most researchers agree that the answer is to be found in a combination of the following possible explanations. Genetically manipulated crops, inbreeding, chemical pesticides, parasites, stress from modern industrial bee management, where bee colonies are shipped on trucks between huge mono crops that require fertilization, are all part of the problem. ${ }^{5}$ The issue most frequently identified is the use of chemicals in modern farming. In particular, the use of neonicotinoid pesticides can be linked to the mass death of bees. This pesticide is spread in plant tissues and is deadly to insects throughout the growing season, including during flowering when honey bees consume their pollen. Neonicotinoids affect insects' central nervous system. Some studies show how neonicotinoids affected the bees' ability to navigate. ${ }^{6}$ Another reaction is that even very small amounts of neonicotinoids deteriorate the reproductive ability of bumblebees, another important pollinating insect. ${ }^{7}$

In Sweden gains and losses in bee stock have been documented for almost 100 years. Sweden has not suffered from mass death of bees, which is reported in other parts of the world. In Sweden the bees, in recent years, have hibernated relatively well due to warm winters. There is also a completely different pressure on the usage of pesticides and chemicals in agriculture in Sweden compared to other countries, as many Swedish beekeepers fight mites using organic methods. It is illegal to use substances such as neonicotinoids in crops that are attractive to bees or other pollinators. So even if pesticides are a problem for pollinators internationally, this is less of an issue in Sweden. The spread of the varroa mite is a far greater problem for Swedish bees. ${ }^{8}$

Last year's media attention on the mass death of bees has affected both people and companies. Disasters often trigger human reaction to prevent further deterioration or extinction. The mass death of bees is linked to money for most of us, as we are nearly all

\footnotetext{
${ }^{4}$ D. Engelsdorp and J.S. Pettis, "Colony Collapse Disorder”, in Bee Health and Veterinarians, edited by W. Ritter (2014).

${ }^{5}$ Pedersen et al., Massdöd av bin - samhällsekonomiska konsekvenser och möjliga åtgärder.

${ }^{6}$ J.P. van der Sluijs et al., "Neonicotinoids, Bee Disorders and the Sustainability of Pollinator Services", Current Opinion in Environmental Sustainability 5 (2013): 293-305.

${ }^{7}$ C. Lu et al., "Sub-lethal Exposure to Neonicotinoids Impaired Honey Bees Winterization before Proceeding to Colony Collapse Disorder”, Bulletin of Insectology 67 (2014): 125-30.

${ }^{8}$ Pedersen et al., Massdöd av bin - samhällsekonomiska konsekvenser och möjliga åtgärder.
} 
invested in stock markets through pension funds and other forms of institutional investment, and stock markets are clearly affected. ${ }^{9}$ This financial connection also creates a great opportunity for marketing and sales of products that in one way or another can be associated with honey or pollinating bees. As a reaction several companies donated money to bee research: for example the cosmetics chain The Body Shop donated 20 Swedish kronor per sold product of one of their make-up series for three weeks in summer 2011 to the Swedish Beekeepers Association. ${ }^{10}$

Many companies are not satisfied with simply donating money or demonstrating concern for the bees in their advertising. Instead, some companies try to get involved in other ways. One way they are involving themselves in bee decline is by introducing beehives close to their corporate buildings, such as in courtyards, on terraces or on rooftops. This type of initiative is a new and increasingly common phenomenon in Sweden. In this chapter, we discuss this corporate use of beehives as a means of demonstrating sustainable development; we explore corporate accountability in relation to bee populations and the impact of these initiatives on urban biodiversity and environment.

\section{The value of pollination}

There are many signs that the threat to life on the planet and the loss of biodiversity has to be taken seriously. There are about 1,900 species of pollinating bees and bumblebees in Europe, $20 \%$ of them are endemic and many of these are threatened with extinction, according to the IUCN Red List. ${ }^{11}$ In Germany, for instance, there are 560 bee species and 289 of them are on the red list. Every loss of pollinating species means a step nearer an approaching collapse of ecosystems that depend on pollination, which threatens our food production. Many experts speak of a global pollination crisis. ${ }^{12}$ About $75 \%$ of all crop species require pollination by

\footnotetext{
${ }^{9}$ See Chapters $1,11,12,13$ and 16.

${ }^{10}$ B. Johansson, Make up med honung för mångfalden. Bitidningen. Sveriges Biodlares Riksförbund, Biodlarna, 2011.

${ }^{11}$ A. Nieto et al., European Red List of Bees (IUCN Global Species Programme, IUCN European Union Representative Office, 2015).

${ }^{12}$ S. Kluser and P. Peduzzi, Global Pollinator Decline: A Literature Review (United Nations Environment Programme, 2007).
} 
animals of some sort. Recent studies suggest that about one-third of pollination is delivered by honey bees, the rest being carried out by a range of wild insects, flies, butterflies, birds or even bats. ${ }^{13}$ If vital pollinators cannot survive or if there are not enough pollinators, farmers will be forced to hand-pollinate crops. This is now happening in a province of China, where hired workers use brushes to hand-pollinate pear trees. ${ }^{14}$ Such measures are possible for a limited number of high-value crops, but there are not enough humans in the world to pollinate all of our crops by hand.

The pollination service of bees has for a long time been economically invisible. In recent years the commercial value of pollination has been calculated. The global annual economic value of insect pollination was estimated to be $€ 153$ billion during 2005 (i.e. $9.5 \%$ of the total economic value of world agricultural output considering only crops that are used directly for human food. ${ }^{15}$ This means that the value of refined products such as pickled cucumbers or tomatoes used for ketchup are not included. The corresponding figure for the value of bee pollination for agriculture in Sweden 2011 has been calculated as approximately $€ 26-47$ million. In Sweden, the value of pollination is estimated as 3\% of the total contribution of agriculture to the Swedish GDP. ${ }^{16}$ In these calculations the value of noncommercial farming such as gardening, pollination of wild plants and berries was not included. The value of honey bee pollination of wild flora is difficult to estimate but probably it is as important as it is for commercial farming. Due to the pollinating crisis and the worrying decline in the number of specialized wild pollinators, humans have become dependent on a super-generalist honey bee visiting a large number of plant species. ${ }^{17}$ Knowing that bees' pollinating service is worth $€ 153$ billion, we may now look at them in a different way, give them a little more attention. There is so much value in a beehive but we humans have not even thought about it.

\footnotetext{
${ }^{13}$ T.D. Breeze et al., "Pollination Services in the UK: How Important are Honeybees?” Agriculture, Ecosystems \& Environment 142 (2011): 137-43.

${ }^{14}$ U.M.A. Patrap et al., "Pollination Failure in Apple Crop and Farmers' Management Strategies in Henduan Mountains, China", Acta Hortic (ISHS) (2001): 225-30.

${ }^{15}$ S.G. Potts et al., "Global Pollinator Declines: Trends, Impacts and Drivers", Trends in Ecology and Evolution 25 (2010): 345-53.

${ }^{16}$ T.R. Pedersen, Värdet av honungsbins pollinering av grödor i Sverige, in Jordbruksverket (ed.), 2011.

${ }^{17}$ M. Rundlof et al., "Seed Coating with a Neonicotinoid Insecticide Negatively Affects Wild Bees", Nature 521 (2015): 77-80.
} 


\section{Pollination in Swedish agriculture}

The term mass death of bees is used collectively for unusually large winter losses and colony collapse disorder (CCD). CCD is quite a new concept, primarily an American and a Canadian phenomenon, but similar symptoms have been recorded in other countries. There is no official registration of the CCD in Sweden, although beekeepers have reported similar symptoms. ${ }^{18}$ The Israeli acute paralysis virus, which is one of the possible causes of CCD, has not been registered in Sweden. Chemicals legislation and the procedure for pesticides approval are considerably stricter in Sweden than in other countries. The whole structure of beekeeping is also different in comparison with countries such as the United States. Beekeeping in Sweden is rather immobile unlike in the United States where beehives are moved around the crops. However, in Sweden there is poor control of the presence of viral diseases and there is a lack of planning to prevent the spread of viruses and mites. Normally the level of winter losses of Swedish bees has been between 5 and 10\% but statistics show that winter losses are increasing and the number of bee colonies has declined in recent years. This could be an effect of many factors, for example a decrease in colony vitality that makes it more vulnerable to parasites, diseases, agricultural poisons and breeding among others. ${ }^{19}$

In 2009, the Swedish Board of Agriculture initiated a project to investigate why honey bees are dying and what can be done to prevent this from happening. The study showed that the varroa mite and associated viruses are the biggest threats to honey bees in Sweden. Several other threats were also identified including: lack of pollen and nectar plants; reduced genetic variation within bee populations because of modern bee breeding; and pesticides such as neonicotinoids. Several projects have started to tackle the threats that have emerged.

One of these projects is "Diversity on the plain". In this project farmers in areas with intensive agricultural production are saving plants that honey bees, bumblebees and other bees thrive in. The decline in farmland biodiversity is often said to be a result of agricultural intensification and structural changes in the agricultural landscape. ${ }^{20}$ Contemporary agricultural landscapes often lack forage resources for pollinators. The intensification of agriculture with larger fields, efficient and diverse cultivation and denser crops are some

\footnotetext{
${ }^{18}$ Pedersen et al., Massdöd av bin - samhällsekonomiska konsekvenser och möjliga åtgärder.

${ }^{19}$ Ibid.

${ }^{20}$ M. Rundlöf and H.G. Smith, "The Effect of Organic Farming on Butterfly Diversity Depends on Landscape Context”, Journal of Applied Ecology 43 (2006): 1121-7.
} 
explanations for the disappearance of pollinators. ${ }^{21}$ Flower strips and field islets, using ditch banks and honing are examples of methods to manage the decline of pollinators. The aim of the project was to encourage farmers in the plains area to implement simple and inexpensive measures to protect biodiversity, as far as is possible, while even improving agricultural profitability. ${ }^{22}$

Sweden also has a national programme to improve the production and marketing of apiculture products. In 2013, the Swedish Board of Agriculture introduced The National Honey Program. Two out of the programme's four objectives are connected to increasing the bee population and decreasing winter death. The average number of bee colonies should increase by $2 \%$ over a period of three years from the 2013 level for at least two-thirds of the counties. The decline in winter mortality during the current programme period will be lower than the corresponding winter mortality for the previous period.

A project called the pollination pool started by the "Swedish Professional Beekeepers" makes it possible for plant growers and beekeepers to rent and let bee colonies for pollination assignments. With the help of pollination services plant growers can increase the harvest without increasing the amount of fertilizer or the area of cultivated land. Swedish research has shown that there can be a yield increase of up to $20 \%$ by adding two beehives per hectare. $^{23}$

Another project will develop a new contingency plan for mites and other bee pests, as well as examining the impacts of neonicotinoids on honey bees, bumblebees and solitary bees under field conditions in Sweden. This is an extension of the 2009 study on the economic consequences of and possible interventions in colony losses in honey bees. ${ }^{24}$ The current project is continuing with threats of plant protection products and exotic pests.

\section{Bees in Swedish cities}

In addition to national Swedish agricultural programmes, there has been a growing interest among firms in adopting beehives and placing them in cities. A new type of "employment

\footnotetext{
${ }^{21}$ R. Bommarco et al., "Drastic Historic Shifts in Bumble Bee Community Composition in Sweden", Proceedings of the Royal Society B. Biological Sciences 279 (2012): 309-15.

${ }^{22}$ S. Eriksson and M. Rundlöf, Pollinatörer i insådda ettåriga blomremsor - en fältundersökning av förekomsten av blombesökande insekter i insådda blommande remsor i tre slättbygdsområden i Sverige 2011-12. Hushållningssällskapet, 2013.

${ }^{23}$ Biodlingsföretagarna, Öka skörden med pollineringspoolen. Hallvigs tryckeri, 2010.

${ }^{24}$ Pedersen et al., Massdöd av bin - samhällsekonomiska konsekvenser och möjliga åtgärder.
} 
agency" is becoming more common, which rents bees instead of a human workforce. Instead of "man power" these agencies provide "bee power".

Contrary to what we might expect, bees are doing well in the city. Cities often provide a huge diversity of sites: gardens, meadows and nature reserves. All of these habitats can add up to a really special resource for pollinators. There is a wide variety of flowers and other plants on balconies, terraces, discounts and allotment gardens and lots of flowers. This ensures that bees will find pollen during a greater part of the year. Within cities there is more varied bee food. Hence, bees will be more efficient and can produce more honey in each hive. Moreover, it tends to be slightly warmer in cities than in the countryside. This makes it easier for bees to over-winter. Studies show that bees do not seem to be affected significantly by the exhaust gases from vehicles and in town we use fewer agricultural poisons compared with use in the countryside. Samples have been taken from both urban bees and their honey to investigate contamination. However, there have been no findings of contamination in the honey and the bees showed no raised levels of toxins. Nonetheless, cities are often bereft of bees and wild pollinators. Therefore, an increase in urban beekeepers could both serve as insurance for the bees' survival and for pollination of plants.

\section{Research methods}

We started by searching all companies on the Stockholm Stock Exchange, OMX, for beerelated disclosures. Due to its voluntary nature, bee-related disclosure may appear anywhere in corporate communications. Therefore, all website sections were examined, not just the sustainability sections. That process required examination of archives, presentations, news announcements, company brochures and reports in electronic form, as well as corporate activity in social media. Companies' websites, online information and documents were searched for words related to: bee(s), honey, pollination and beehives. Since we only got a few hits the search was broadened to all Swedish companies. This resulted in the finding that it seems to be a new trend for companies to engage in hosting beehives on rooftops or company premises. The study therefore focuses on companies that are hosting beehives.

This study comprises 32 companies from the following sectors: (17) property and/or municipal housing; (3) transportation (airport, railway); (5) hotel and conference; (1) 
architecture; (1) energy; (1) marketing; (2) culture (opera house); (1) food production; and (1) recycling.

Four years of annual and sustainability reports (2011 to 2014), if available, were analysed for all companies. In addition, the content on companies' websites, blogs and Facebook pages or other social media were studied.

We conducted two stages of analysis. First we performed a content analysis to extract themes from the bee-related disclosures. Second we looked at bee-related initiatives why did companies engage in bees; this could later be included in the themes.

In this study we applied a range of different content analysis such as meaning oriented and interpretive content analysis. This implies that we are looking for the underlying themes in the texts as an interpretative content analysis assuming that words derive their meanings when they are used in specific situations. By looking at words and phrases in their context (paragraph or whole text) we can discover themes that exist independently from the interpreter. $^{25}$

\section{Bees disclosure by Swedish companies}

In reports and websites of Swedish listed companies, just a few companies disclosed information about bees. Searching more widely on Swedish companies and the link to bees, we found that there was great interest on the part of companies to invest in bees and beehives as part of their sustainability work. Companies in the real estate business were most devoted to this type of activity; 17 of the 32 companies in this study belong to this group. Several companies that let and manage hives for large companies have, in recent years, entered the market. The hives are placed on the roofs of company buildings, preferably in the middle of large cities or nearby places where emission takes place.

Companies that invested in beehives were mainly to be found in large cities: 18 of the companies are located in Stockholm, nine in the area of Gothenburg, three in Malmö, one in Karlstad and one in Västerås. We can also see that the companies are focused in a few industries, mainly the property industry and municipal housing as noted above (17 of 32).

\footnotetext{
${ }^{25}$ M. Smith and R.J. Taffler, “The Chairman's Statement: A Content Analysis of Discretionary Narrative Disclosures", Accounting Auditing \& Accountability Journal 13 (2000): 624-46.
} 
Five firms were hotels, three belonged to the transportation sector, railways and airport. Two belonged in the culture sector; here beehives were placed on top of the cities' opera houses. The rest belonged to energy, recycling, architecture, food production and marketing business.

The review of corporate information regarding bee-related disclosure has shown that the information is available at various locations within the corporate communications. Out of the 32 studied companies, 14 provided the information in the company's annual report, 10 featured bee disclosure in the sustainability report. Three of these companies disclosed the information in both the annual and the sustainability report; one of the studied firms had an integrated report. All companies provided information on the website, one had a blog and another had a Facebook page; we also looked at Twitter accounts.

The information disclosed by companies that rent or own hives varies between companies. In most cases there is information on the company's website where they disclose their environmental commitment in general, adding information about the beehives and the purpose of keeping bees. Some of the companies link the information to more than an ecological value and also mention an economic value.

After studying 32 company websites, annual reports, sustainability reports and other documents it can be noticed that the available corporate disclosure concerning involvement in bees and beehives can be categorized into six themes. These themes are described below.

\section{Contributing to biodiversity}

Out of the 32 analysed companies, 17 write that they want to contribute to biological diversity. Above all it is the bee's role as pollinator the companies are writing about. Bees play an important role for both biodiversity and a sustainable society. The pollination of the neighbourhood, especially in cities, is a factor that contributes to biodiversity. There are also disclosures about the importance of spreading knowledge about the bee's role in the ecosystem since bees have an important function to play in biodiversity and a sustainable society. If the companies are committed to such things they say that they "take the environmental efforts to the next level". By investing in hives they put things in a "larger perspective", which "inspires others", and increases understanding of the importance of biodiversity. This applies particularly in urban environments. "Together we will spread awareness of the importance of increased biodiversity and the bee's role in our ecosystem".

\section{Corporate social responsibility}


Investing in beehives could be one part of a company's CSR work. It is a way of portraying themselves as respecting the environment and showing local commitment. Some use the bees as a way to be target-oriented and goal-oriented with respect to environmental issues. Since honey and other products from the bees are sold, companies can also, as a part of their CSR work, donate all surpluses to non-profit organizations or for charitable purposes. Research shows the importance of corporate philanthropy as a mechanism to support economic prosperity and growth, especially when it comes to urgent social purposes. Surplus donations to charity fit well with this view.

\section{Responsible property ownership}

Most of the studied real estate companies say that they are taking care of all tenants, bees as well as humans, big as well as small. One writes that "our latest, and maybe most important tenants, are smaller than what we're used to - they are bees" another that "we like to take care of all our tenants humans as well as bees". Sometimes bees are mentioned as part of the staff. "Our new staff, the worker bees, makes sure we get a lot of fruit in autumn". Taking care of the tenants is what many of the companies refer to as responsible property ownership. Similarities between bees and companies in the real estate business are highlighted. Among several of the property companies, colonies of bees are compared with human society. Similarities include the fact that bees are very sociable; they undergo various stages of maturity akin to humans (i.e. children and adults); and they have different types of tasks or work. One example of this is when a company writes "Bees take care of their children in a similar ways as humans". Or, "bees, like humans are working, make sure that there is enough food in the larder and help each other to keep warm in the winter". There is some discussion in the corporate discourse of bees as community builders, which are very diligent and concerned with health and safety. One property company wrote that "...to become a sponsor for a beehive is an excellent way to bring to life an environmental policy and sustainability initiatives for both employees and tenants." The more a company can add ecological value, by planting vegetation on the roofs, establishing plantations, beehives, wetlands or other initiatives, the more it increases the value of the environmental project and the more durability points serve the company as a whole. The purpose is often talked about as a willingness to be involved and take responsibility for society, a way of giving back to nature.

\section{Raising awareness of bee decline and the pollination crisis}


With small and simple but valuable contributions companies hope that they could contribute to bee survival and help to raise awareness of global bee deaths and the pollination crisis. Bees are in a precarious position around the world. Hence, spreading knowledge is of utmost importance. By raising the issue and spreading knowledge about the work bees are doing through pollination, people could become aware and influence decision-makers to take action against global bee death and the pollination crisis.

\section{Measuring performance}

Especially for companies in the transportation sector, bees are used as performance

measurers. Malmö Airport has an ongoing project with bees and bee products, which serves as an environmental indicator for assessing air quality around the airport. Honey bees are considered to be good indicators of chemical pollution in the environment in two ways. First, bees experience high mortality rates when in contact with pesticides and second their bodies and products accumulate pollutants, which can be measured in laboratories. Comparative analysis between the bees on and far from the airport has shown no significance difference between air pollution levels between measuring points. Also the honey and beeswax produced in hives near the airport were analysed to show which chemical substances are present in the bees' environment. Having beehives on airport runways could also been seen as a way of neutralizing $\mathrm{CO}_{2}$ emissions and reducing the carbon footprint. This could be known as a "Bees as 21 st century canaries" theme as they are being used in the same way that canaries in cages were used to detect gas in mines.

\section{Education}

Many of the beehives are also used for education. The hives are placed on the ground and are built so that anyone is able to look in behind secure glass to see how the bees live and work. Some of the companies are also sponsoring activities for schools; the bee rental companies, hiring the hives to other companies, are educating young children in school about the life of bees and the value of pollinators. 


\section{Discussion}

A large number of studies ${ }^{26}$ use legitimacy theory in an attempt to explain CSR disclosures in annual reports. Most of such disclosures focus on general sustainability and most companies provide little if any information on their impact on ecosystems. ${ }^{27}$ A previous study shows that less than one-third of Swedish companies report such information. ${ }^{28}$ Legitimacy theory assumes that the legitimacy of a firm to operate in society depends on a social contract between the firm and the society. ${ }^{29}$ Legitimacy theory also assumes that companies will adopt disclosure strategies to conform to society's expectations. ${ }^{30}$ According to legitimacy theory, a company needs to have legitimacy in the sense of a social "licence to operate". ${ }^{31}$ Without this "licence" a company won't access the necessary resources to successfully conduct business. If society perceives that a company is not operating in an acceptable way, legitimacy will be potentially threatened. Companies use disclosure to enhance their "corporate image" and strengthen their "corporate identity". 32

\footnotetext{
${ }^{26}$ See, for example, J. Guthrie and L.D. Parker, "Corporate Social Disclosure Practice: A Comparative International Analysis", Advances in Public Interest Accounting 3 (1990): 159-75; D.M. Patten, "Exposure, Legitimacy and Social Disclosure”, Journal of Accounting Public Policy 10 (1991): 297-308; D.M. Patten, "Intra-industry Environmental Disclosures in Response to the Alaskan Oil Spill: A Note on Legitimacy Theory", Accounting, Organizations and Society 17 (1992): 471-5; C. Deegan and M. Rankin, "Do Australian Companies Report Environmental News Objectively? An Analysis of Environmental Disclosures by Firms Prosecuted Successfully by the Environmental Protection Authority", Accounting, Auditing \& Accountability Journal 9 (1996): 50-67; and D.J. Campbell, "Legitimacy Theory or Managerial Reality Construction? Corporate Social Disclosure in Marks \& Spencer Corporate Reports, 1969-1997”, Accounting Forum 24 (2000): 80-100.

${ }^{27}$ M.J. Jones and J.F. Solomon, "Problematising Accounting for Biodiversity", Accounting, Auditing \& Accountability Journal 26 (2013): 668-87.

${ }^{28}$ G. Rimmel and K. Jonäll, "Biodiversity Reporting in Sweden: Corporate Disclosure and Preparers' Views”, Accounting, Auditing and Accountability Journal 26 (2013): 746-78.

${ }^{29}$ J. Guthrie and L.D. Parker, "Corporate Social Reporting: A Rebuttal of Legitimacy Theory", Accounting and Business Research 19 (1989): 343-52.

${ }^{30}$ C. Deegan, “The Legitimising Effect of Social and Environmental Disclosures: A Theoretical Foundation”, Accounting, Auditing, \& Accountability Journal 15 (2002): 282-311.

${ }^{31}$ Ibid.

${ }^{32}$ R. Hooghiemstra, "Corporate Communication and Impression Management: New Perspectives Why Companies Engage in Corporate Social Reporting”, Journal of Business Ethics 27 (2000): 55-68.
} 
The companies studied demonstrate through the act of investing in beehives that they are engaging in what is for humanity an important and urgent matter. By investing in hives and additionally disclosing information about their engagement with bees, the firms demonstrate that the issue of pollination is taken seriously. Previous research ${ }^{33}$ has shown that companies report to their stakeholders in order to legitimize corporate activities. In this study, however, it seems that action itself is more important than reporting. Especially, since the information is sketchy and if disclosed it is the specific action that the companies inform about and bees are in focus. When it comes to the property and municipal housing companies we studied, there is a link between their own business, their activities and beekeeping. They compare the beehives to their own houses, the colonies to the residents and the bees' work to the employees' work. They also write that beekeeping is a part of corporate sustainability initiatives, especially linked to the local area; by investing in a hive the firms show local commitment to pollination and diversity.

Hahn and Kühnen conclude in their summary of previous research that companies want to signal good performance; this implies a positive effect on reporting. They also conclude that companies with a less sustainability work and performance may face greater stakeholder pressure. Consequently, companies may be more actively engaged in reporting to mitigate legitimacy threats. This implies a negative relation between performance and sustainability reporting. ${ }^{34}$

What has been observed in this study is that the amount of disclosure from the companies regarding bee-related information is not very large in the reports to shareholders or investors. Most information is given on the corporate website or in the companies' magazines aimed at the residents. When it comes to the property and municipal housing companies, it is the residents who are targeted. The content of the disclosure is linked to housing and community. Companies in this sector often compare beehives with their residential properties and bees are also mentioned as new tenants moving in, tenants who will secure biodiversity. Although there is relatively little reporting of bees, the engagement in comparison is relatively large. We can assume that companies do not face legitimacy threats regarding this type of disclosure. The disclosure focuses on positive effects through investing in beehives,

\footnotetext{
${ }^{33}$ See for example R.M. Haniffa and T.E. Cooke, “The Impact of Culture and Governance on Corporate Social Reporting”, Journal of Accounting and Public Policy 24 (2005): 341-430.

${ }^{34}$ R. Hahn and M. Kühnen, "Determinants of Sustainability Reporting: A Review of Results, Trends, Theory, and Opportunities in an Expanding Field of Research”, Journal of Cleaner Production 59 (2013): 5-21.
} 
highlighting the bees' work and proving to be responsible property owners who take care of all tenants, including bees.

For the studied companies in the transportation sector, bees are used as performance measurers. In this case there seems to be a stronger link to corporate legitimacy and focus on showing that the operation meets society's expectations that the companies work for a cleaner environment. Making use of bees as a measure of emissions can be linked to how stakeholders perceive the company. To ensure that emissions are so small that they do not affect sensitive animals also shows that the demands for cleaner vehicles and less pollution are taken seriously and thus contribute to strengthening the company's legitimacy.

In society today there is a call to protect nature and to ensure that diversity is maintained. Biodiversity is a term that includes all variations and all the interactions between plants, animals and their environment. It is important to preserve biological diversity for several reasons. Among other things, functioning ecosystems perform numerous ecological services that we often take for granted. Biodiversity loss is accelerating and this represents one of today's most serious environmental issues. Loss of species affects ecosystems and food security on Earth. From an ecosystems perspective, taking an integrated approach to bee decline, the loss or severe decline in one particular species can have catastrophic and unknown consequences on other species and on nature as a whole. The demand for organic food increases gradually as consumer awareness increases. The honey produced in companies' beehives is often packaged in a way that conveys the message that the company's brand stands for sustainable development and biodiversity. The companies' disclose their beekeeping in a way that gets people to start talking about what happens in nature around us. There are many companies working proactively to reduce their environmental impact and find business opportunities in the conservation of biodiversity and ecosystem services. That companies contribute to biodiversity or at least not destroy it is one of the conditions for companies to gain legitimacy. The bees bring environmental benefits and companies that place hives on their plots or roofs receive goodwill.

The importance of pollination for human food production has been a hot topic, especially after the threats of extinction of bees have been highlighted in the media. As an extended discussion of biodiversity many of the companies in the study intend to increase awareness of global bee deaths and the pollination crisis. This ensures that information and knowledge will be spread that can contribute to bee conservation. 


\section{Some reflections and possibilities}

Through the interpretative content analysis we found five major themes in the bee-related disclosures. Companies were quite eager to communicate that they contributed to biological diversity by hosting bees. Beekeeping was also a part of the companies' CSR work and also a way of portraying themselves as respecting the environment and showing local commitment. The majority of the studied companies were in the property and/or municipal housing sector. These firms compared the beehives to human society and observed many similarities between bees and humans.

Among companies in the central parts of Stockholm and other big cities, having their own hives has become the latest way to communicate sustainability and ecological awareness among clients and competitors. Companies will in this way spread knowledge and information about bees and biodiversity and how they relate to sustainable urban development and human well-being.

For decades, companies have used disclosures about sustainability, climate change and ecosystems to create a picture of being a "good company". Some of these words have been overused and have become outdated; companies need something new to lean on. Using bees engages the public in a natural way since many are aware of the problems with diminishing numbers of pollinators. Installing beehives near company properties is fantastic for building public awareness about both the company and nature without using words.

Table 14.1 Overview of Swedish company bee-related disclosure 
Information in

\begin{tabular}{|c|c|c|c|c|}
\hline Swedavia Malmö & airport & 0 & 20112013 & $\mathrm{x}$ \\
\hline Swedavia Landvetter & airport & 0 & 0 & $\mathrm{x}$ \\
\hline Jernhusen & railway & 2014 & 0 & $\mathrm{x}$ \\
\hline Borås energi & Energy & 2014 & 0 & blog \\
\hline Ibis Arlanda & hotel & 0 & 2012 & $\mathrm{x}$ \\
\hline Clarion Arlanda & hotel & 0 & 0 & $\mathrm{x}$ \\
\hline Hotel Hilton Slussen & hotel & 0 & 0 & $\mathrm{x}$ \\
\hline Bee Production & marketing content företag & 0 & 0 & $\mathrm{x}$ \\
\hline Familjebostäder & municipal housing & 0 & 0 & $\mathrm{x}$ \\
\hline Bostadsbolaget & municipal housing & $2013 \quad 2014$ & 2013 & $\mathrm{x}$ \\
\hline Stockholmshem & municipal housing & 20132014 & 0 & $\mathrm{x}$ \\
\hline Poseidon & municipal housing & 0 & 0 & $\mathrm{x}$ \\
\hline Wihlborgs fastigheter & property & 0 & 2014 & $\mathrm{x}$ \\
\hline Brostaden (Castellum) & property & 0 & $2013 \quad 2014$ & $\mathrm{x}$ \\
\hline Axfast (Axel Johnson koncernen) & property & 2013 & 0 & $\mathrm{x}$ \\
\hline Chalmersfastigheter & property & 2014 & 0 & $\mathrm{x}$ \\
\hline Aspholmen fastigheter (Castellum) & property & 0 & 20132014 & $\mathrm{x}$ \\
\hline AFA fastigheter & property & 0 & 0 & $\mathrm{x}$ \\
\hline AMF fastigheter & property investment and development & 0 & 2013 & $\mathrm{x}$ \\
\hline Skanska & property and construction & 2013 & 0 & $\mathrm{x}$ \\
\hline Löfbergs Lila & food production & 0 & 20132014 & $\mathrm{x}$ \\
\hline Operahuset i Malmö & Operahouse & 0 & 0 & $\begin{array}{l}\text { facebook } \\
\text { twitter }\end{array}$ \\
\hline Göteborgs Operan & Operahouse & 2012 & 0 & $\mathrm{x}$ \\
\hline IK Recycling & Recycling & 2013 & integrated & blog \\
\hline
\end{tabular}

$<$ TS: please reinput and set as native table. Start cells with a capital letter $>$ 


\section{References}

Biodlingsföretagarna. Öka skörden med pollineringspoolen. Hallvigs tryckeri, 2010.

Bommarco, R., O. Lundin, H.G. Smith and M. Rundlöf. "Drastic Historic Shifts in Bumble Bee Community Composition in Sweden”. Proceedings of the Royal Society B. Biological Sciences 279 (2012): 309-15.

Breeze, T. D., A.P. Bailey, K.G. Balcombe and S.G. Potts. "Pollination Services in the UK: How Important are Honeybees?" Agriculture, Ecosystems \& Environment 142 (2011): 137-43.

Campbell, D. J. "Legitimacy Theory or Managerial Reality Construction? Corporate Social Disclosure in Marks \& Spencer Corporate Reports, 1969-1997”. Accounting Forum 24 (2000): 80-100.

Deegan, C. "The Legitimising Effect of Social and Environmental Disclosures: A Theoretical Foundation". Accounting, Auditing, \& Accountability Journal 15 (2002): 282-311.

Deegan, C. and M. Rankin. "Do Australian Companies Report Environmental News Objectively? An Analysis of Environmental Disclosures by Firms Prosecuted Successfully by the Environmental Protection Authority”. Accounting, Auditing \& Accountability Journal 9 (1996): 50-67.

Engelsdorp, D. and J.S. Pettis. “Colony Collapse Disorder”. In Bee Health and Veterinarians, edited by W. Ritter. 2014. Eriksson, S. and M. Rundlöf. Pollinatörer i insådda ettåriga blomremsor - en fältundersökning av förekomsten av blombesökande insekter i insådda blommande remsor i tre slättbygdsområden i Sverige 2011-12. Hushållningssällskapet, 2013.

Guthrie, J. and L.D. Parker. "Corporate Social Reporting: A Rebuttal of Legitimacy Theory”. Accounting and Business Research 19 (1989): 343-52.

Guthrie, J. and L.D. Parker. "Corporate Social Disclosure Practice: A Comparative International Analysis". Advances in Public Interest Accounting 3 (1990): 159-75.

Hahn, R. and M. Kühnen. "Determinants of Sustainability Reporting: A Review of Results, Trends, Theory, and Opportunities in an Expanding Field of Research". Journal of Cleaner Production 59 (2013): 5-21.

Haniffa, R. M. and T.E. Cooke. "The Impact of Culture and Governance on Corporate Social Reporting”. Journal of Accounting and Public Policy 24 (2005): 341-430.

Holland, N. "The Economic Value of Honeybees”. BBC News, 2009

Hooghiemstra, R. "Corporate Communication and Impression Management: New Perspectives Why Companies Engage in Corporate Social Reporting”. Journal of Business Ethics 27 (2000): 55-68.

Johansson, B. Make up med honung för mångfalden. Bitidningen. Sveriges Biodlares Riksförbund, Biodlarna, 2011.

Jones, M. J. and J.F. Solomon. "Problematising Accounting for Biodiversity". Accounting, Auditing \& Accountability Journal 26 (2013): 668-87.

Kluser, S. and P. Peduzzi. Global Pollinator Decline: A Literature Review. United Nations Environment Programme, 2007. Lu, C., K.M. Warchol and R.A. Callahan. "Sub-lethal Exposure to Neonicotinoids Impaired Honey Bees Winterization before Proceeding to Colony Collapse Disorder". Bulletin of Insectology 67 (2014): 125-30. 
Nieto, A., S. P. M. Roberts, J. Kemp, P. Rasmont, M. Kuhlmann, M. García Criado, J.C. Biesmeijer, P. Bogusch, H.H. Dathe, P. De La Rúa, T. De Meulemeester, M. Dehon, A. Dewulf, F.J. Ortiz-Sánchez, P. L’homme, A. Pauly, S.G. Potts, C. Praz, M. Quaranta, V.G. Radchenko, E. Scheuchl, J. Smit, J. Straka, M. Terzo, B. Tomozii, J. Window and D. Michez. European Red List of Bees. IUCN Global Species Programme, IUCN European Union Representative Office, 2015.

Patrap, U. M. A., T.E.J. Patrap and H.E. Yonghua. "Pollination Failure in Apple Crop and Farmers' Management Strategies in Henduan Mountains, China”. Acta Hortic (ISHS) (2001): 225-30.

Patten, D. M. "Exposure, Legitimacy and Social Disclosure”. Journal of Accounting Public Policy 10 (1991): 297-308.

Patten, D. M. "Intra-industry Environmental Disclosures in Response to the Alaskan Oil Spill: A Note on Legitimacy Theory". Accounting, Organizations and Society 17 (1992): 471-5.

Pedersen, T. R. Värdet av honungsbins pollinering av grödor i Sverige. In: Jordbruksverket (ed.), 2011.

Pedersen, T. R., R. Bommarco, K. Ebbersten, A. Falk, I. Fries, P. Kristiansen, P. Kryger, H. Nätterlund and M. Rundlöf. Massdöd av bin - samhällsekonomiska konsekvenser och möjliga åtgärder (Rapport 2009:24). Jönköping: Jordbruksverket, 2009.

Potts, S. G., Biesmeijer, J. C., Kremen, C., Peter, N., Oliver, S. and E., K. W. "Global Pollinator Declines: Trends, Impacts and Drivers". Trends in Ecology and Evolution 25 (2010): 345-53.

Rimmel, G. and K. Jonäll. "Biodiversity Reporting in Sweden: Corporate Disclosure and Preparers' Views”. Accounting, Auditing and Accountability Journal 26 (2013): 746-78.

Rundlöf, M. and H.G. Smith. "The Effect of Organic Farming on Butterfly Diversity Depends on Landscape Context". Journal of Applied Ecology 43 (2006): 1121-7.

Rundlof, M., G.K.S. Andersson, R. Bommarco, I. Fries, V. Hederstrom, L. Herbertsson, O. Jonsson, B.K. Klatt, T.R. Pedersen, J. Yourstone and H.G. Smith. "Seed Coating with a Neonicotinoid Insecticide Negatively Affects Wild Bees". Nature 521 (2015): 77-80.

SASS, J. Busy as a Bee: Pollinators Put Food on the Table. National Resources Defense Council, 2015.

Smith, M. and R.J. Taffler. "The Chairman's Statement: A Content Analysis of Discretionary Narrative Disclosures". Accounting Auditing \& Accountability Journal 13 (2000): 624-46.

van der Sluijs, J. P., N. Simon-Delso, D. Goulson, L. Maxim, J-M. Bonmatin and L.P. Belzunces. "Neonicotinoids, Bee Disorders and the Sustainability of Pollinator Services". Current Opinion in Environmental Sustainability 5 (2013): 293-305.

van Engelsdorp, D., J.D. Evans, C. Saegerman, C. Mullin, E. Haubruge, B.K. Nguyen and J.S. Pettis. "Colony Collapse Disorder: A Descriptive Study". PLoS ONE (2009). 